\title{
Relationship between lower limb anthropometry and temporo-spatial parametersin gait of young adults Relación entre la antropometría de miembro inferior y los parámetros temporo-espaciales en la marcha de adultos jóvenes \\ *Oscar Valencia, *Oscar Araneda, *Marcela Cárcamo, **Felipe Carpes, *Rodrigo Guzmán-Venegas \\ *Universidad de los Andes (Santiago, Chile), ** Universidad Federal de Pampa (Uruguaiana, RS, Brasil)
}

\begin{abstract}
Temporo-spatial parameters (TSP) are commonly used to characterize human gait. These help to differentiate population groups in different conditions of gait, but can be influenced by lower limb anthropometry. Different strategies are assumed to normalize TSP and permit comparison among people. However, it is not clear how dimensions of the different lower limb segments influence gait TSP. The aim of this study was to verify the relationship between gait TSP and length of the thigh, leg and foot in young adults. The body segments lengths were adjusted for individual height and correlated with gait TSP. We found a correlation between foot length and step width ( $\mathrm{r}=0.44)$. When data were adjusted for gender, step time, stride time, cadence and gait speed correlated with foot length in men ( $r=0.51,0.49,-0.49$ and -0.43 , respectively). Among women, these same TSP correlated only with thigh length $(r=0.43,0.46,-0.47$ and -0.37 , respectively). Step and stride length correlated with leg ( $\mathrm{r}=0.46$ and 0.48$)$ and thigh length ( $r=0.44$ and 0.44 ) only in men. In conclusion, anthropometric parameters influence TSP differentially for men and women. These data should be considered when studying population groups including people from both genders.
\end{abstract}

Key words: human gait, temporo-spatial parameters, lower limb anthropometry.

Resumen. Los parámetros temporo-espaciales (PTE) son comúnmente usados para caracterizar la marcha humana. Estos ayudan a diferenciar grupos de poblaciones en diferentes condiciones de marcha, pero pueden ser influenciados por la antropometría de miembro inferior. Diferentes estrategias asumen la normalización de PTE y permiten comparar entre personas. Sin embargo, no está claro como las dimensiones de los diferentes segmentos de miembro inferior influyen los PTE en la marcha. El objetivo de este estudio fue verificar la relación entre los PTE de la marcha y la longitud del muslo, pierna y pie en adultos jóvenes. Las longitudes de los segmentos corporales fueron ajustadas por la altura de cada persona y correlacionadas con los PTE de la marcha. Se encontró una correlación entre la longitud del pie y el ancho del paso ( $\mathrm{r}=0.44)$. Cuando los datos fueron ajustados por género, el tiempo del paso, tiempo de la zancada, cadencia y velocidad de la marcha correlacionaron con la longitud del pie en hombres ( $\mathrm{r}=0.51$, 0.49 , -0.49 and -0.43 , respectivamente). Entre las mujeres, estos mismos PTE solo correlacionaron con la longitud del muslo ( $\mathrm{r}=0.43,0.46$, -0.47 and -0.37 , respectivamente). La longitud del paso y la zancada correlacionaron con la longitud de la pierna ( $\mathrm{r}=0.46$ and 0.48$)$ y el muslo ( $\mathrm{r}=0.44$ and 0.44$)$ solo en hombres. En conclusión, los parámetros antropométricos influyen de forma diferente los PTE para hombre y mujeres. Estos datos podrían ser considerados cuando se estudian grupos de poblaciones incluyendo personas de ambos géneros.

Palabras claves: marcha humana, parámetros temporo-espaciales, antropometría de miembro inferior.

\section{Introduction}

Human gait is a motor task with biomechanical characteristics unique in comparison to other animals (O’Neill et al., 2015). Previous studies suggest that evolution plays a major role in the definition of anthropometric characteristics in humans, especially concerning segment dimensions and its effects on running economy (Guedes, Franzini, Júnior, Maria, \& Morales, 2017; Raichlen, Armstrong, \& Lieberman, 2011; Rolian, Lieberman, Hamill, Scott, \& Werbel, 2009). Therefore, anthropometric characteristics need to be considered when analyzing biomechanical data from gait (Šentija, Rakovac, \& Babiæ, 2012).

Kinematics and kinetics characteristics as well as temporo-spatial parameters (TSP) are common variables to the study of human gait (Cadenas-Sánchez, López-Contreras, \& Arellano, 2015; Cimolin \& Galli, 2014; Elvira, Plaza, Valenciano, \& Montero, 2017; Eng \& Winter, 1995; Froehle, Nahhas, Sherwood, \& Duren, 2013; Ganley \& Powers, 2005). TSP depends on displacement of the lower extremities, with respect to time and space. It has previously been reported that TPS are affected by anthropometric factors (Hof, 1996; Titianova, Pitkänen, Pääkkönen, Sivenius, \& Tarkka, 2003), such as height, leg length and sitting height, which are known to influence gait speed (Šentija et al., 2012). Lower limb length is commonly used to normalize walking speed, cadence, stride and step length (Hof, 1996; Kirtley, 2006). However, whether TSP measures may suffer greater influence of a specific lower limb segment still is unclear. Therefore, the aim of this study was to verify the relationship between gait TSP and the length of the thigh, leg and foot in young people. Furthermore, anatomical dimensions differ between men and women (Fessler, Haley, \& Lal, 2005; Lim et al., 2013; Tomassoni, Traini, \& Amenta, 2014), and therefore a secondary purpose in this study was to determine the influence of gender on the relationship between gait TSP and length of lower limbs segments.

Fecha recepción: 09-05-17. Fecha de aceptación: 26-09-17 Oscar David Valencia Cayupán ovalencia@uandes.cl

\section{Methods}

In this analytical cross-sectional study, young participants attending university were evaluated, both men and women, aged between 18 and 24 years old, who participated voluntarily. Considering data on segments length reported Sentija, Rakovac, \& Babic(2012), sample size considering an alpha of 0.01 and a power of $90 \%$ was calculated using GPower $^{\circ}$ (version 3.1.9.2, Kiel Universität, Germany). A minimum sample size of 48 volunteers was obtained, distributed equally between men and women.

Fifty four university students voluntarily joined this study (women: 27, age: $21 \pm 1$ years old, body mass: $55.52 \pm 5.92 \mathrm{~kg}$, height: $1.63 \pm 0.05$ m; men: 27 , age: $21 \pm 1$ years old, body mass: $73.77 \pm 9.94 \mathrm{~kg}$, height: $1.76 \pm 0.05 \mathrm{~m}$ ). All participants who showed musculoskeletal and neurological problems affecting the gait, for example, asymmetric lower limbs, traumatic lesions involving hip, knee and ankle joints, etc. were not considered. The procedures in this study were in agreement with the Helsinki declaration and the local institution committee of ethics in research with humans approved this research protocol.

\section{Procedures}

Participants completed a session of gait analysis including kinematic and kinetic measures at self-selected gait speed. Gait was evaluated through a 3D motion analysis system with eight infrared cameras (TSeries; Vicon Motion Systems, Oxford, UK), recording the movement at $100 \mathrm{~Hz}$ and three force plates (Bertec, FP4060-05-PT-1000, USA) positioned at the floor level, recording ground reaction forces at a frequency of $1000 \mathrm{~Hz}$. Force data were used to detect gait events (heel strike and toe off). Movement was reconstructed based in position data obtained from tracking of 39 spherical reflective markers with a diameter of $14 \mathrm{~mm}$ placed at specific anatomical points in accordance with the Plug-in Gaitmodel (Davis, Õunpuu, Tyburski, \& Gage, 1991; Kadaba, Ramakrishnan, \& Wootten, 1990). Once the reflective markers were fixed, volunteers were asked to walk on a flat surface 8 meters long, at self-selected gait speed.

Body mass, height and anthropometry data from both lower limb 
were reported, considering the following (Buendía-Lozada et al., 2017; Nor et al., 2013; Pheasant \& Haslegrave, 2016): lower limb length (distance from the anterior superior iliac spine to the medial malleolus), thigh length (distance from the greater trochanter to the lateral point of tibia), leg length (distance from lateral point of tibia to the lateral malleolus of ankle), and foot length (distance from the most prominent point of the calcaneus to the most prominent toe, usually the first or second toe).

\section{Data analysis}

TSP of each gait were calculated using a gait analysis software (Polygon 4.1, Vicon Motion Systems, UK). Table 1 shows the definition of each TSP (Cámara Tobalina, 2011; Hollman, McDade, \& Petersen, 2011). Data analyses considered both absolute and normalized TSP. Data were normalized considering the individual body height.

\section{Statistical analysis}

Shapiro-Wilk test was used to verify data distribution. Data were described by the mean and standard deviation. Pearson or Spearman correlation coefficients were calculated to verify the relationship between TSP and thigh, leg and foot length in men and women. Correlation coefficients were interpreted as: $\mathrm{r} d » 0.35$ low correlation, from 0.36 to 0.67 moderate correlation and between 0.68 to 1.0 high correlation (Taylor, 1990). Independent samples t-student or the Mann-Whitney $\mathrm{U}$ test were used to compare the length of the lower limb segments between men and women. All statistical analyses were performed considering two-tailed tests, with a confidence level of $95 \%$ and an alpha of 0.05 using a commercial statistical package (STATA, version 12.0, StataCorp LP, USA).

\section{Results}

Table 2 describes the demographic characteristics and absolute length of the lower limb segments. Segments' lengths were adjusted for body height as shown in Table 3.

Body mass ( $p<0.0001)$, height $(p<0.0001)$, length of the lower limb ( $p<0.0001)$, leg length $(p<0.0001)$ and foot length $(p<0.0001)$ were higher in men compared to women. The adjusted length of the thigh was higher in women than men $(\mathrm{p}<0.0001)$, whereas the adjusted length of the foot was higher in men $(\mathrm{p}=0.002)$. No difference was observed in the adjusted length of the leg between the groups (Table 3) Considering the entire sample(Table 4), a significant correlation between the adjusted length of the foot and the stride width $(r=0.44, p=0.001)$ was observed.

Among men, the adjusted length of the foot correlated to four TSP (Table 5): cadence $(r=-0.49, p=0.01)$, step time $(r=0.51, p=0.007)$, stride time $(r=0.49 ; p=0.009)$ and gait speed $(r=-0.43, p=0.027)$. Additionally, TSP of step and stride length correlated to thigh length ( $\mathrm{r}$ $=0.48, \mathrm{p}=0.011 ; \mathrm{r}=0.44, \mathrm{p}=0.022)$ and leg length $(\mathrm{r}=0.46, \mathrm{p}=0.016$ $\mathrm{r}=0.44 \mathrm{p}=0.021)$ adjusted for body height, respectively.

Among women, the adjusted length of the thigh significantly correlated to four TSP(see Table 6): cadence $(r=-0.47, p=0.007)$, step time $(\mathrm{r}=0.43, \mathrm{p}=0.013)$ stride time $(\mathrm{r}=0.46, \mathrm{p}=0.008)$ and gait speed $(r=-0.37, p=0.028)$.

\section{Discussion}

\section{Relationship between segment length and TSP}

The purpose of our study was to verify the correlation between TSP and anthropometric of the lower extremity during gait in women and men. When considering the entire sample, step width and length of the foot were only moderately correlated $(r=0.44)$, with no further associations between the lengths of the others segments and TSP. This result most likely relies on the relationship between foot length and body height (Krishan \& Kanchan, 2013; Krishan, Kanchan, Passi, \& DiMaggio, 2012; Tobias, Duke George, Vitalis, \& Baxter-Grillo, 2014). It can be assumed that with a higher height, there is also an increase in the
Table 1.

\begin{tabular}{|c|c|c|}
\hline TSP & Definition & Unit \\
\hline Step length & $\begin{array}{l}\text { Distance between successive contact points of alternate feet with the } \\
\text { floor. }\end{array}$ & $\mathrm{m}$ \\
\hline Stride length & $\begin{array}{l}\text { Distance in the direction of progression between successive points of } \\
\text { support of the same foot on the floor. }\end{array}$ & $\mathrm{m}$ \\
\hline Step width & $\begin{array}{l}\text { Distance between two lines of progression generated by the contact of } \\
\text { the left and right heel with the floor. }\end{array}$ & $\mathrm{m}$ \\
\hline Step time & $\begin{array}{l}\text { Time elapsed between the first contact of one foot with the floor and the } \\
\text { first contact of the opposite foot. }\end{array}$ & $\mathrm{s}$ \\
\hline Stride time & $\begin{array}{l}\text { Time interval between two successive supports of the same foot on the } \\
\text { floor. }\end{array}$ & $\mathrm{s}$ \\
\hline Cadence & Number of steps one person takes at a given time. & steps/min \\
\hline Gait speed & Distance (displacement) walked by a person at a given time. & $\mathrm{m} / \mathrm{s}$ \\
\hline
\end{tabular}

Demographic characteristics and absolute lengths of the segments of the assessed sample, $\mathrm{n}=54$ (mean \pm SD).

\begin{tabular}{lcc} 
& Men $(\mathrm{n}=27)$ & Women $(\mathrm{n}=27)$ \\
\hline Age (years) & $20.70 \pm 1.49$ & $20.70 \pm 1.33$ \\
Mass $(\mathrm{kg})$ & $73.77 \pm 9.94$ & $55.52 \pm 5.92 * * * *$ \\
Height $(\mathrm{m})$ & $1.76 \pm 0.05$ & $1.63 \pm 0.05 * * * *$ \\
Lower limb $(\mathrm{m})$ & $0.93 \pm 0.04$ & $0.85 \pm 0.03^{* * * *}$ \\
Thigh $(\mathrm{m})$ & $0.39 \pm 0.03$ & $0.39 \pm 0.02$ \\
Leg $(\mathrm{m})$ & $0.45 \pm 0.02$ & $0.41 \pm 0.02^{* * * *}$ \\
Foot $(\mathrm{m})$ & $0.26 \pm 0.01$ & $0.23 \pm 0.01^{* * * *}$ \\
\hline $\mathrm{t}$-student, ${ }^{* * * *} \mathrm{p}<0.0001$ & &
\end{tabular}

t-student, **** $\mathrm{p}<0.000$

Table 3.

Length of segments of the lower limb adjusted for body height, $\mathrm{n}=54$ (mean $\pm \mathrm{SD}$ ).

\begin{tabular}{lcc} 
& Men $(\mathrm{n}=27)$ & Women $(\mathrm{n}=27)$ \\
\hline Lower $\operatorname{limb}(\mathrm{m} / \mathrm{m})$ & $0.53 \pm 0.01$ & $0.52 \pm 0.01$ \\
Thigh $(\mathrm{m} / \mathrm{m})$ & $0.22 \pm 0.01$ & $0.24 \pm 0.01^{* * * *}$ \\
Leg $(\mathrm{m} / \mathrm{m})$ & $0.26 \pm 0.01$ & $0.25 \pm 0.01$ \\
Foot $(\mathrm{m} / \mathrm{m})$ & $0.15 \pm 0.005$ & $0.14 \pm 0.005^{* *}$ \\
\hline $\mathrm{t}-$ student, ${ }^{* *} \mathrm{p}<0.01,{ }^{* * * *} \mathrm{p}<0.0001$ &
\end{tabular}

t-student, ** $\mathrm{p}<0.01, * * * * \mathrm{p}<0.0001$

Table 4.

Correlation coefficients between anthropometric variables (adjusted for body height) and temporo-spatial parameters, considering the total of the sample $(\mathrm{n}=54)$.

\begin{tabular}{|c|c|c|c|c|}
\hline & Lower limb & Thigh & Leg & Foot \\
\hline Step length (m) & 0.13 & 0.16 & 0.15 & -0.07 \\
\hline Stride length (m) & 0.10 & 0.13 & 0.13 & -0.05 \\
\hline Step width (m) & 0.14 & -0.25 & 0.01 & $0.44^{* *}$ \\
\hline Step time (s) & -0.06 & 0.09 & -0.09 & 0.20 \\
\hline Stride time (s) & -0.08 & 0.09 & -0.11 & 0.22 \\
\hline Cadence (steps/min) & 0.06 & -0.11 & 0.10 & -0.23 \\
\hline Gait speed $(\mathrm{m} / \mathrm{s})$ & 0.12 & 0.00 & 0.14 & -0.18 \\
\hline
\end{tabular}

$* * \mathrm{p}<0.01$

Table 5.

Correlation coefficients between anthropometric variables (adjusted for body height) and temporo-spatial parameters in men $(\mathrm{n}=27)$.

\begin{tabular}{|c|c|c|c|c|}
\hline & Lower limb & Thigh & Leg & Foot \\
\hline Step length (m) & 0.12 & $0.48^{*}$ & $0.46^{*}$ & -0.20 \\
\hline Stride length (m) & 0.10 & $0.44 *$ & $0.44^{*}$ & -0.17 \\
\hline Step width (m) & 0.00 & 0.33 & -0.05 & 0.25 \\
\hline Step time (s) & 0.05 & 0.12 & -0.10 & $0.51^{* *}$ \\
\hline Stride time (s) & 0.03 & 0.12 & -0.09 & $0.49 * *$ \\
\hline Cadence (steps/min) & -0.07 & -0.12 & 0.08 & $-0.49 *$ \\
\hline Gait speed $(\mathrm{m} / \mathrm{s})$ & 0.01 & 0.15 & 0.27 & $-0.43^{*}$ \\
\hline
\end{tabular}

Gait speed $(\mathrm{m} / \mathrm{s})$

$* \mathrm{p}<0.05, * * \mathrm{p}<0.01$

Table 6. Correlation coefficients between anthropometric variables (adjusted for body height) and temporo-spatial parameters in women $(\mathrm{n}=27)$.

\begin{tabular}{lcccc}
\hline & Lower limb & Thigh & Leg & Foot \\
\hline Step length $(\mathrm{m})$ & 0.12 & 0.10 & -0.21 & -0.13 \\
Stride length $(\mathrm{m})$ & 0.09 & 0.05 & -0.24 & -0.11 \\
Step width $(\mathrm{m})$ & 0.25 & -0.06 & 0.06 & 0.25 \\
Step time $(\mathrm{s})$ & -0.17 & $\mathbf{0 . 4 3}$ & -0.04 & -0.21 \\
Stride time $(\mathrm{s})$ & -0.19 & $\mathbf{0 . 4 6 *}$ & -0.06 & -0.19 \\
Cadence $(\mathrm{steps} / \mathrm{min})$ & 0.20 & $\mathbf{- 0 . 4 7 *}$ & 0.07 & 0.18 \\
Gait speed $(\mathrm{m} / \mathrm{s})$ & 0.26 & $\mathbf{- 0 . 3 7 ^ { * }}$ & -0.06 & 0.15 \\
\hline Shown data represent the r value of Pearson or Spearman correlation coefficient, as appropriate.
\end{tabular}

$* \mathrm{p}<0.05$

base of support to ensure postural stability, since the center of mass is at higher position (Lugade, Lin, \& Chou, 2011; Rosker, Markovic, \& Sarabon, 2011). In this context, the increase in step width could increase the base of support in the medial-lateral direction aiming at stability (Cadenas-Sánchez et al., 2015), which could explain the correlation between the length of the foot and step width found in this study.

\section{Effects of gender on TSP and correlations with anthropometric} parameters

As depicted by our results, anthropometric parameters of men and women at similar age did differ. Therefore, TSP normalization was investigated considering such differences. These findings could be explained by anthropometric differences (adjusted for body height) between men and women (Guedes et al., 2017). In the assessed sample, the thigh length of women was greater than that of men, in proportion to body height $($ women $=0.24 \mathrm{v} / \mathrm{s}$ men $=0.22 ; \mathrm{p}<0.0001$ ). Men presented foot longer than women $($ women $=0.14 \mathrm{v} / \mathrm{s}$ men $=0.15$; $\mathrm{p}=$ 
0.002). Additionally, there are previous backgrounds which have described a direct relationship between the variation of body height and stride length (Hausdorff, Zemany, Peng, \& Goldberger, 1999). Considering the above mentioned, there is no information linking the segmental components of the lower limb with the TSP, except for the present study.

Regardless of gender, cadence and gait speed are inversely related to different segment lengths. Sutherland (1994) also described an inverse relationship, but considering the lower limb length on cadence (Kirtley, 2006). Moreover, there is evidence of a strong direct relationship ( $r$ $=0.8$ ) between cadence and speed (Kirtley, 2006), possibly linking the simultaneous decrease in these variables with the longitudinal variation of the foot segment, in men, and thigh, in women.

The results of this study support the proposals of other authors (Chao, Laughman, Schneider, \& Stauffer, 1983; Hof, 1996), in relation to the need to adjust the TSP to the length or height of the lower limb of each person, thus eliminating any possible bias caused by anthropometric differences. So far, no differences in length of the thigh, leg or foot, given the gender, have been considered when adjusting TSP. On the other hand, differences between men and women found in this study should be considered when analyzing samples containing men and women in the same groups, which could involve a source of bias, if the analysis variables include TSP.

\section{Conclusion}

Length of the thigh, leg and foot segments (adjusted for body height) correlated with TSP during gait at preferred speed. There is a relationship between the step width and foot length. On the other hand, gender had an influence on the relationship between the TSP and anthropometric variables. In men, the length of the thigh, leg and foot with TSP was related; while in women, only TSP with the length of the thigh was related. When analyzing the TSP in the gait, the variation of these body segments should be considered, especially when comparing men and women.

\section{Conflict of interest statement}

The authors declare they have no conflict of interest.

\section{Acknowledgments}

The authors would like to thank:»Fondo de Ayuda a la Investigación (FAI), Universidad de los Andes, Santiago, Chile»

\section{References}

Buendía-Lozada, E. R. P., Cruz-Gómez, M. A., Flores-Chico, B., AguilarEnríquez, R. I., Villagrán-Arroyo, E. I., Sánchez-Flores, O., \& Lópezde-la-Rosa, L. E. (2017). Ecuaciones de predicción de pliegues cutáneos en escolares. Revista Internacional de Medicina Y Ciencias de La Actividad Física Y Del Deporte, 17(65), 27-41.

Cadenas-Sánchez, C., López-Contreras, G, \& Arellano, R. (2015). Revisión de la biomecánica de la marcha en medio acuático vs terrestre. Retos, 28, 128-133.

Cámara Tobalina, J. (2011). Análisis de la marcha: sus fases y variables espacio-temporales. Entramado, 7(1), 160-173.

Chao, E. Y., Laughman, R. K., Schneider, E., \& Stauffer, R. N. (1983). Normative data of knee joint motion and ground reaction forces in adult level walking. Journal of Biomechanics, 16(3), 219-233.

Cimolin, V., \& Galli, M. (2014). Summary measures for clinical gait analysis: A literature review. Gait \& Posture, 39(4), 1005-1010.

Davis, R. B., Õunpuu, S., Tyburski, D., \& Gage, J. R. (1991). Agait analysis data collection and reduction technique. Human Movement Science, 10(5), 575-587.

Elvira, J., Plaza, D., Valenciano, A., \& Montero, C. (2017). Influencia de calzado en el movimiento del pie durante la marcha y la carrera en niños y niñas de 6 y 7 años. Retos, 31, 128-132.

Eng, J. J., \& Winter, D. A. (1995). Kinetic analysis of the lower limbs during walking: What information can be gained from a three-dimensional model? Journal of Biomechanics, 28(6), 753-758.
Fessler, D. M. T., Haley, K. J., \& Lal, R. D. (2005). Sexual dimorphism in foot length proportionate to stature. Annals of Human Biology, 32(1), 44-59.

Froehle, A. W., Nahhas, R. W., Sherwood, R. J., \& Duren, D. L. (2013). Age-related changes in spatiotemporal characteristics of gait accompany ongoing lower limb linear growth in late childhood and early adolescence. Gait \& Posture, 38(1), 14-19.

Ganley, K. J., \& Powers, C. M. (2005). Gait kinematics and kinetics of 7year-old children: a comparison to adults using age-specific anthropometric data. Gait \& Posture, 21(2), 141-145.

Guedes, D. P., Franzini, P. C., Júnior, R. P., Maria, J., \& Morales, M. (2017). Anthropometry and Physical Fitness of Latin American Adolescents. Retos, 31, 264-270.

Hausdorff, J. M., Zemany, L., Peng, C.-K., \& Goldberger, A. L. (1999). Maturation of gait dynamics: stride-to-stride variability and its temporal organization in children. Journal of Applied Physiology (Bethesda, Md./ : 1985), 86(3), 1040-1047.

Hof, A. L. (1996). Scaling gait data to body size. Gait \& Posture, 4(3), 222-223.

Hollman, J. H., McDade, E. M., \& Petersen, R. C. (2011). Normative spatiotemporal gait parameters in older adults. Gait \& Posture, 34(1), 111-118.

Kadaba, M. P., Ramakrishnan, H. K., \& Wootten, M. E. (1990). Measurement of lower extremity kinematics during level walking. Journal of Orthopaedic Research, 8(3), 383-392.

Kirtley, C. (2006). Clinical gait analysis: theory and practice (First, pp. 15-37).

Krishan, K., \& Kanchan, T. (2013). Foot length is a functional parameter for assessment of height. The Foot, 23(1), 54-55.

Krishan, K., Kanchan, T., Passi, N., \& DiMaggio, J. A. (2012). Stature estimation from the lengths of the growing foot-A study on North Indian adolescents. The Foot, 22(4), 287-293.

Lim, H.-C., Bae, J.-H., Yoon, J.-Y., Kim, S.-J., Kim, J.-G., \& Lee, J.-M. (2013). Gender differences of the morphology of the distal femur and proximal tibia in a Korean population. The Knee, 20, 26-30.

Lugade, V., Lin, V., \& Chou, L.-S. (2011). Center of mass and base of support interaction during gait. Gait \& Posture, 33(3), 406-411.

Nor, F. M., Abdullah, N., Mustapa, A.-M., Qi Wen, L., Faisal, N. A., \& Ahmad Nazari, D. A. A. (2013). Estimation of stature by using lower limb dimensions in the Malaysian population. Journal of Forensic and Legal Medicine, 20(8), 947-952.

O’Neill, M. C., Lee, L.-F., Demes, B., Thompson, N. E., Larson, S. G., Stern, J. T., \& Umberger, B. R. (2015). Three-dimensional kinematics of the pelvis and hind limbs in chimpanzee (Pan troglodytes) and human bipedal walking. Journal of Human Evolution, 86, 32-42.

Pheasant, S., \& Haslegrave, C. (2016). Bodyspace: Anthropometry, ergonomics and the design of work (Third).

Raichlen, D. A., Armstrong, H., \& Lieberman, D. E. (2011). Calcaneus length determines running economy: Implications for endurance running performance in modern humans and Neandertals. Journal of Human Evolution, 60(3), 299-308.

Rolian, C., Lieberman, D. E., Hamill, J., Scott, J. W., \& Werbel, W. (2009). Walking, running and the evolution of short toes in humans. Journal of Experimental Biology, 212(5), 713-721.

Rosker, J., Markovic, G., \& Sarabon, N. (2011). Effects of vertical center of mass redistribution on body sway parameters during quiet standing. Gait \& Posture, 33(3), 452-456.

Šentija, D., Rakovac, M., \& Babiæ, V. (2012). Anthropometric characteristics and gait transition speed in human locomotion. Human Movement Science, 31(3), 672-682.

Taylor, R. (1990). Interpretation of the Correlation Coefficient: A Basic Review. Journal of Diagnostic Medical Sonography, 6(1), 35-39.

Titianova, E. B., Pitkänen, K., Pääkkönen, A., Sivenius, J., \& Tarkka, I. M. (2003). Gait characteristics and functional ambulation profile in patients with chronic unilateral stroke. American Journal of Physical Medicine \& Rehabilitation, 82(10), 778-786.

Tobias, D. K. E., Duke George, D. M., Vitalis, M. E., \& Baxter-Grillo, P. D. (2014). Sexual Dimorphism of Correlations of feet anthropometric parameters and Height (stature) among Undergraduate students of a University, Western Nigeria. IOSR Journal of Dental and Medical Sciences, 13(4), 46-53.

Tomassoni, D., Traini, E., \& Amenta, F. (2014). Gender and age related differences in foot morphology. Maturitas, 79, 421-427. 